\title{
Heritage and tourism: from opposition to coproduction
}

\section{Maria Gravari-Barbas}

Why another book on heritage tourism? What is there still to be said after the considerable number of books and articles published on the subject over recent years? The bibliography on the interrelation between tourism and heritage is certainly extensive and multidimensional (Timothy 1997; Graham et al. 2000; Lazzarotti 2003; Timothy and Boyd 2003; Gonzalez 2008; Timothy and Nyaupane 2009; Timothy 2011; Bourdeau et al. 2015, 2017). However, are there any blind spots that call for a renewed research agenda?

Tourism and heritage are two collaborative phenomena. Tourism has played a major, though relatively unexplored, role in the emergence and affirmation of the modern notion of heritage. The concept of "historical monument" emerged in the West at the turn of the nineteenth century, concomitantly with tourism development and affirmation. The synchronous, parallel and sometimes even complicit way in which these two phenomena have emerged is indicative of their collaborative nature. From its very beginnings in the eighteenth century, tourism has been attracted by beauty, by the picturesque and by singularity. As such, it has been one of the primary elements in the recognition of heritage-to-be. It has contributed to the identification of places "awakened", or even revealed, by the “outsider's" touristic gaze (Urry 1990).

In this sense, tourism has been one of the most powerful factors in the social production of heritage. The ambition of this book is to bring new light to the ways tourism and heritage have reciprocally impacted, transformed and transmuted each other. To do so, we will highlight recent changes in both the heritage and tourism paradigms. We will discuss their relationship and, beyond that, their reciprocal coproduction. The aim of this book is therefore to suggest new paths for future research on the multiple and dynamic interrelations between heritage and tourism. 


\section{A new heritage regime}

In the last decades of the twentieth century, there was a shift in the notion of cultural heritage. The approach to it changed from object-centred to subject-centred, focusing less on the heritage object itself and more on its multiple, intangible social and relational potentialities. Moving progressively away from "sacralized" objects towards functions, it has come to be understood more as an agent and a process, incorporating social, cultural and environmental issues (Gravari-Barbas 2014). This has dramatically changed the role it plays in the cultural, social and economic domains. Major heritage texts and conventions, such as the Faro Convention (2005) and the UNESCO Convention of Intangible Heritage (2003), have marked a conceptual, philosophical and ethical turn towards democratic and human values through the anchoring of heritage, cultural and human rights at the centre of a renewed understanding of cultural heritage.

A number of factors have jointly influenced the way cultural heritage is conceived and managed in contemporary societies. Globalization, societal changes, the hybridization of lifestyles and practices (hypermobility, multiple associative and social ties and cultural affiliations, multi-territoriality, urbanization, multi-nuclear families, blurring of genders, etc.), environmental and climate-related risks, micro- and macro-economic changes, digital technology evolutions and the cross-cutting relations of cultural heritage with other sectors are just some of the factors that have contributed to the reformulation of the heritage realm and the relationship contemporary societies build with it.

These global societal evolutions have contributed to a "new heritage regime" (Gravari-Barbas 2014) that forms a system within the new phase of globalization and calls into question the heritage "stock" of a nation or a defined social group. The attributes of this new heritage regime are:

Blurring of heritage categories: Specific heritage categories have been defined in major conventions such as the UNESCO Convention on World Heritage (1972) and the UNESCO Convention on Intangible Heritage (2003). However, heritage is increasingly seen as a transversal issue, extending beyond its tangible and intangible aspects to also include natural and cultural heritage. It is becoming increasingly difficult to justify the construction of rigid categories.

Plurality and complexity in heritage production: The desire for heritage among individuals and societies is fed by an ever-growing number of different actors. The continuous expansion of heritage leads to a re-examination and question- 
ing of the hierarchies constructed. Heritage stakeholders at different levels (policy makers, heritage practitioners and local communities, the academic world) all contribute to the dynamic production of cultural heritage, opening up the possibility of making it a source of democracy and well-being (Grossi et al. 2011).

New heritage "producers": The increasing number of heritage objects and the acceleration of heritage-making are considered to be signs of change within the heritage system, characterized by new heritage producers, values, functions, meanings and heritage levels (from local to international).

Heritage values are constantly and dynamically reinterpreted: Heritage conservation is dynamic, directed towards increased sustained use defined by both change and continuity. The "regulatory function" that conservation provides for contemporary landscapes can go beyond, and play a more important role than, the simple conservation of heritage artefacts.

The new heritage regime now places cultural heritage at the very centre of current social, economic and cultural considerations. Heritage can be a means to achieve sustainable goals and social justice and to guarantee empowerment of heritage communities (Adell et al. 2015).

\section{A renewed tourism paradigm}

In a former paper (Gravari-Barbas et al. 2019), we underlined the recent "velvet revolution" in tourism. Although models of mass tourism still prevail in most tourism areas, bringing increasing numbers of tourists into "overtouristified" areas (Peeters et al. 2018), a paradigmatic shift can be observed in terms of both tourism offer and demand. Segments of tourists that have accumulated significant "tourism capital" through their numerous travels and their capacity to adapt and to feel "at home" wherever they are (Maitland 2010) express the desire for alternative models of tourism. These "mature" tourists feel the need to venture outside the designated tourist enclaves imagined for them, far from places subverted by other tourists (Delaplace and Gravari-Barbas 2016a). Local tourism providers have responded to the demand from these experienced tourists and adapted their touristic offers accordingly.

These developments are also associated with the digital turn and the emerging so-called "collaborative economy" (Botsman and Rogers 2011). They involve not only the tourists but also the different types of actors in the tourism system. 
They are shaking up the established tourism landscape and prompting hybridization processes that bring new actors, places and practices into the tourism arena (Delaplace and Gravari-Barbas 2016b). In particular, tourism practices appear to be increasingly disintermediated (as non-professional providers offer tourism services to tourists without the mediation of the "market"). Tourists are increasingly attracted by practices related to everyday life, with local communities playing an ever-greater role in the tourism economy. Over the last decades of the twentieth century, tourism evolved towards a multifaceted and pervasive phenomenon that lost its specificity (dedicated places resorts, tourist zones, etc. - and dedicated players). New tourism cultures have emerged as a result of the visitor's desire to go beyond the urban tourist enclave zones to experience the city "as a local", to interact more with local communities, to experience off-the-beaten-track neighbourhoods, to be thrilled by "urban exploration" activities and to be amazed by ordinary, everyday life (Condevaux et al. 2019; Frisch et al. 2019).

The concept of hyper-tourism (Condevaux et al. 2016) testifies to the accumulation and diversification of practices and to the tourist's shift from a more mainstream tourism (characterized by commercially promoted products by providers established or concentrated in established tourism locations) to alternative tourism.

The broadening of the heritage concept mentioned above must therefore be seen in relation to these new forms of tourism. Both New Belgrade (Nicic and Iguman 2019) and the Nowa Huta district of Krakow (Banaszkiewicz, Chapter 8 in this book) have become tourism destinations concomitantly to their heritagization, which transformed the socialist urbanism into heritage artefacts. The touristification of the Chernobyl Exclusion Zone supports its heritagization (Banaszkiewicz, Chapter 8), again prompting the "chicken-or-the-egg" question: is tourismification encouraging heritagization, or vice versa? By offering meanings, memories and history, heritage sites also provide the basis for a more experiential tourism, personally and affectively connecting with the visitors.

\section{You said heritage tourism?}

A review of the literature on heritage tourism reveals - despite the authors' different approaches and disciplinary backgrounds as well as the different times the papers were written - some constant lines of definition: "Heritage tourism refers to travelers seeing or experiencing built heritage, living culture 
or contemporary arts (. . .) Heritage tourism is supposed to be place-bound, as opposed to cultural tourism, dominant in urban areas and is less bound" (Timothy 2011: 4-5). For Park (2014: 1), "Heritage tourism is predominantly concerned with exploring both material (tangible) and immaterial (intangible) remnants of the past." Park considers that "heritage tourism is inextricably bound up with experiencing both material (tangible) and socio-psychological (intangible) remnants of the nation's past" (Park 2010: 116). For Fyall and Garrod (1998), heritage tourism is an economic activity that makes use of socio-cultural assets to attract visitors. Scarpaci (2005: 7) considers heritage tourism to be "the industry of travel that promotes cultural landscapes that hold historical and symbolic landmarks, monuments and neighborhoods".

Although these definitions show the importance of heritage attractions, they offer a rather essentialist approach to heritage tourism. The essentialization of heritage is common in disciplines that focus mainly on (heritage) artefacts rather than on the relationships these artefacts have with individuals and social groups (as mentioned before with the example of the Faro Convention approach). Social science disciplines are not exempt from such an approach.

Most authors consider that heritage already exists as heritage before tourism arrives. Analyses of heritage-tourism nexus generally approach tourism as a phenomenon that is induced by existing heritage assets, which are a posteriori discovered and "consumed" by tourists. Because tourism is assumed to come after heritage, most research studies emphasize its ambiguous and even destructive impact on heritage. This also explains a rather deep-rooted consideration of tourism as a threat to heritage. Most studies focus on the impact of tourism on heritage by stressing the risks of physical (wear and tear) (Fyall and Garrod 1998; Berg 2018) or symbolic destruction (commodification, tourismification, “fantasy storytellings", etc.) (Jansen-Verbeke 1998).

Analyses comparing the parallel historical emergence of these two notions remain rare (Lazzarotti 2003). Few definitions have moved away from the heritage attractions per se to the tourists and their motivations as constitutive of the visited heritage. However, Poria et al. defined heritage tourism as “a phenomenon based on visitors' motivations and perceptions rather than on specific site attributes" (Poria et al. 2001: 1047). In addition, Smith (2012: 213) pertinently noted that "Heritage sites are not simply 'found', nor do they simply 'exist', but rather they are constituted at one level by the management and conservation processes that occur at and around them and, at another level, by the acts of visiting and engagement that people perform at them." These analyses understand heritage as strategic political positions rather than as fixed or essential qualities of specific sites or cultural practices. They inter- 
pret heritage tourism as a possibly congruent phenomenon that also participates in local, national or transnational political games (Smith 2012).

We intend in this book to consider the relationship between heritage and tourism as one that is amphidromic and reciprocal (Figure 1.1). On the one hand, tourism is certainly attracted by sites, buildings, areas or arts and crafts already recognized as heritage, and contributes to their touristification. On the other hand, by its action, it contributes to redefining the scope and symbolic meaning of the then touristified heritage (Gravari-Barbas 2018).

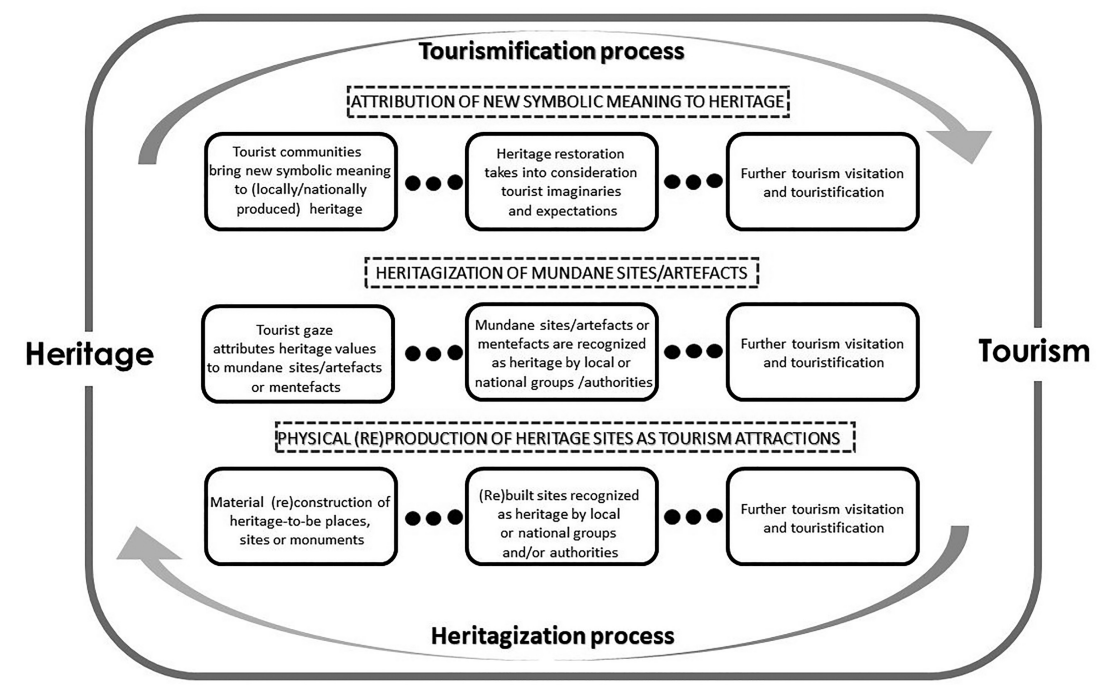

Source: Maria Gravari-Barbas.

Figure 1.1 The amphidromic relationships between heritage and tourism

\section{What does tourism do to heritage?}

Although several pending questions still remain (Does tourism really destroy heritage? Is tourism truly a contributor to the local economy and, if so, under what conditions?), these two aspects have been covered over the years by academic research and professional contributions (Gravari-Barbas and Jacquot 2008). In order to build a future research agenda, we focus here on the transformative effects of tourism on heritage. 


\section{Tourism as a heritage storyteller}

Heritage often depends entirely on the stories being created, recreated and retold. Heritage tourism involves the multiplication of gazes and voices on heritage. Behind every heritage object - whether "local" or UNESCO World Heritage - is a storytelling that is produced by individuals and groups for reasons that go beyond its supposedly intrinsic aesthetic, cultural or artistic value. When a locally produced heritage object (through a bottom-up process - the attribution of heritage values by local communities - or a more top-down approach by the state) is visited by national and international tourism, this storytelling evolves to embrace alternative values, understandings or feelings. Tourists visit with their gaze, feelings and sensitivities (Waterton and Watson 2014: 24). Colonial heritage is enriched and complemented by alternative voices, whether those of the former colonized, who will introduce stories of violence and domination, or those of the former colonizers, who will eventually come to view their own national and colonial heritage differently.

Heritage storytellings evolve not just with the pluralization of voices brought by tourism. Change often comes as a result of the heritage promoters themselves, who feel the need to adapt heritage storytelling to their tourists. This can be for promotional reasons (to enhance their appeal and/or a mundane or complex story) or for political reasons (not to aggrieve other nationalities in the case of war heritage or sensitivities in the case of dark heritage; to embrace post-colonial discourses in the case of colonial heritage). In this sense, heritage tourism contributes to the ideological framing of history and identity (Park 2014: 3).

Tourism contributes to the reconstruction of "landscapes of nostalgia" (Xie 2015: 1) through the idealized touristic framing of the past. Tourists indeed engage with heritage objects by framing them in certain ways (Waterton and Watson 2014: 5). We should not forget that heritage tourism is also a visual field, awash with images and representations (Waterton and Watson 2014: 13) unimaginable without photography (Garrod 2009).

\section{Tourism as a heritage rescaler}

Heritage tourism is becoming an increasingly significant component of the global tourism industry (Park 2014: 3 ). The new heritage regime mentioned above must be understood within the context of globalization. While nation states continue to play an important role in heritage policies (including those relating to UNESCO World Heritage), the circulation of experts, models and international standards is considerably modifying the contours of heritage 
development, introducing a new set of levels, from local to global, and contributing to the globalized production of heritage (Salazar 2005).

The most obvious globalization of heritage has been driven by UNESCO's international labelling since the World Heritage Convention of 1972 (Labadi and Long 2010). Its relationship to the globalization process is again fundamentally ambivalent (Cousin 2008). On the one hand, UNESCO seeks to fight against the destructive effects of the new stage of economic globalization. On the other, it participates in a globalization of values and contributes to a transnational circulation of experiences and the construction of international standards. Heritage development is undertaken both to fit with its logics via the attractiveness of territories within a globalized world and to combat its destructive effects via regulation. These movements are also exerted through the identity and economic empowerment of indigenous cultures. These dynamics of globalization concern tourism and heritage institutions, NGOs, consulting firms, tourism and heritage entrepreneurs, and mobile populations.

The mobilities of transnational elites play a major role in the heritage development of sites, objects and traditions. This concerns both business mobilities, which contribute to the aesthetic and heritage "upgrading" of places of professional life, and the residential elites, who, between their Moroccan riads, Parisian pieds-à-terre and second homes in Kenya, determine the resulting recognition of heritage through their multi-territorialized positioning and sensitivities. This relationship is certainly dialectical, making this recognition the product of an exchange with local populations. However, the fact remains that the global community looks at, selects, sorts and elevates to the status of heritage objects, places that would possibly have had other destinies within the context of a differently compartmentalized world (Gravari-Barbas 2018). The modalities of heritage production are therefore changing in the globalization context, which impacts the process of heritage production by intersecting heritagization with global phenomena such as hypermobility, communication and information flows, and transfers of cultural or aesthetic models.

\section{Tourism as a heritage-producing machine}

Alsayyad's book, Consuming tradition, manufacturing heritage (2013) focuses on the "manufactured" dimension of heritage and the role tourism plays in this process. Upton (2013) mused rhetorically: "How can heritage be manufactured or tradition consumed? 'Manufactured' is often a term of abuse, implying the false, as in a manufactured excuse or situation. Even more, something that is manufactured is artificial, the antithesis of the natural that is so valorized in Euro-American thought" (Upton 2013: 299). However, heritage can only 
be "manufactured" in the first place, symbolically but also physically in some cases, and this does not necessarily challenge heritage authenticity. As Ashworth noted, "History can be true or false: heritage cannot. As a product of the human creative imagination heritage has no authenticity of the object or the historical record; only the authenticity of the experience as perceived by the user" (Ashworth 2009: 80).

Supposing the "constructed" nature of heritage and the fact that it is not a fixed, non-renewable and non-replicable supply were to be acknowledged, the role of tourism in this "manufacturing" process would still need to be discussed (Ashworth 2009). Much of today's heritage tourism offer depends on the staging or re-creation of ethnic or cultural traditions. As Chhabra et al. observed: "satisfaction with a heritage event depends not on its authenticity in the literal sense of whether or not it is an accurate re-creation of some past condition, but rather on its perceived authenticity (consistency with nostalgia for some real or imagined past). Heritage is thus created and re-created from surviving memories, artifacts, and sites of the past to serve contemporary demand" (Chhabra et al. 2003: 705).

The "outsider's" gaze has historically played an important role in the way in which the local is "woken up". It is very often this external gaze that operates a new and unprecedented reading of an artefact and which contributes to the re-evaluation of an object until then considered as banal or mundane. In the nineteenth century, the first tourists, either individually or as members of touring clubs or other groups, began to identify the most attractive landscapes, scenic views and historical monuments, thus producing - and not consuming - them as tourist-heritage objects.

The "touristic gaze" may attribute a heritage status to objects, sites and places not recognized as such by the local population. It contributes to the symbolic transformation and heritagization of an artefact, mentefact or natural site. Tourism is not just a heritage consumer arriving after the heritagization process that symbolically transforms an object into a heritage object has already been completed. However, it certainly acts like it is, which explains, but does not justify, the extensive literature on tourism as a heritage "perverter" or "destroyer". Tourism is also a heritage producer because it bestows new meaning, brought by the imaginary tourism community, which invests heritage sites with their own aesthetic or affective sensibilities.

This is nothing new per se. Tourism has played an important role in the production of heritage both symbolically (recognition and identification of objects by outsiders, i.e. tourists) and physically (orientation of the restoration 
policies) since its beginnings. However, contemporary tourism heritagization is different. It shapes heritage objects that are of a different nature to those produced centrally by states in the nineteenth century in the context of the reaffirmation of state nationalism. The evolution from the nineteenth-century concept of historic monument to heritage is symptomatic of the proliferation of actors involved in the process of heritagization with their multiple aims that go far beyond the affirmation of the nation state (Gravari-Barbas 2018). If tourism has functioned since its beginnings more than two centuries ago as a "heritage producing machine", the globalization and massification of tourism has dramatically accelerated the tourism heritagization process.

The physical (re)constitution of extinct heritage sites, or even the creation of sites that never physically existed before, produces "heritage" artefacts that aim to respond to the experiential demand of tourism. Can the reconstruction of Gaudi's impressive masterpiece, the Sagrada Familia, in Barcelona (in a sense this was the first basilica almost entirely built by tourism funds and almost entirely offered up to a tourism function) be understood without tourism? The Château de Guédelon in Burgundy, which was built from the ground up using traditional construction techniques and which has become a (new) heritage and major tourist site, is emblematic of the ability of tourism to not only give new symbolic (heritage) meaning to existing places but also moreover to produce new heritage materialities.

\section{Book outline}

The 15 chapters in this volume present different research agendas developed by researchers from Europe, North America and Asia and from different linguistic, cultural and disciplinary backgrounds. The book is divided into four main parts in which the research focus adopts four different perspectives.

Part I (Heritage tourism: shifting paradigms) offers a global perspective of the changing paradigm of heritage tourism. Based on the emblematic case of Old Quebec City, Lucie K. Morisset shows what heritage owes to tourism (Chapter 2). She suggests a future tourism research agenda focusing on the narrative of the interrelation between heritage and tourism and on the importance of taking into consideration the "deep time" of the coproduction of heritage and tourism. Chapter 3 by Francesca Cominelli, Aurélie Condevaux and Sébastien Jacquot introduces a research agenda on the transformative impact of intangible cultural heritage ( $\mathrm{ICH}$ ) on the heritage/tourism coupling. Adopting a critical and political perspective, the authors explore the impact of $\mathrm{ICH}$ on 
new types of tourist products and more generally on new types of tourism. Although ICH does not constitute an autonomous field of research, it opens up new ways of understanding the tourist's uses of heritage. In Chapter 4, Dominique Vanneste and Arie Stoffelen challenge the categories of "natural" and "cultural" heritage and advocate a research agenda on the integration of natural and cultural values in heritage tourism.

Part II (Heritage tourism rescalings) focuses on the different levels of the interrelation between heritage and tourism (local, national and international) and the impacts of globalization on heritagization. In Chapter 5, Maria Gravari-Barbas shows the historical background to the production of the Angkor World Heritage site, which was encouraged and planned by the then colonizer according to the prevailing Western understanding of cultural heritage. Current tourism patterns, which are shifting from Europe to Asia, today challenge a heritagization initially customized for a European tourist consumption. Yujie Zhu stresses the dominance of the Western cultural heritage paradigms in heritage tourism studies in Chapter 6. He makes a case for the limitations of a Western-centred, "Western concepts-Chinese application" approach and introduces a research agenda aimed at going beyond Western-centred logics of scholarship. Using Oporto (Portugal) as a case study, Sandra Guinand shows the global forces shaping local heritage in Chapter 7. Drawing on the tourism gentrification and commodification of culture debates, she shows how global platforms such as short-term rentals and global mobilities have contributed to shape Oporto's current heritagescape.

Part III (Heritage tourism: politics matters) looks at the political nature of tourism heritage construction. Based on the post-socialist heritage cases in Central and Eastern Europe (the Nowa Huta district of Krakow and the Chernobyl Exclusion Zone), Magdalena Banaszkiewicz analyses the dissonant dimensions of cultural heritage and the role of tourism in the process of negotiating the meaning of heritage between stakeholders representing different value systems (Chapter 8). Also focusing on post-socialist heritage, in Chapter 9 Marta Derek shows the changing nature of a dissonant heritage in Warsaw, which has been progressively depoliticized and commodified by and for tourism. Mathieu St-Pierre and Pascale Marcotte analyse the impact of tourism narratives and imaginaries on the transformation of war heritage in Chapter 10. By becoming tourists, 'enemies of the past' give new meanings to the battlefields and transform war sites into heritage sites for war tourism. Linda Boukhris questions the legitimizing dominant epistemology of natural heritage that leads to major contradictions, such as the commodification or militarization of conservation in Chapter 11. She shows that the political economy of tourism is central to understanding the performative 
character of the wilderness imaginary and sets up a research agenda on the decolonization of natural heritage through the political economy of tourism. Finally, in Chapter 12, based on a case study of Baltimore city (USA), Maria Gravari-Barbas shows the political role tourism development played in the heritagization of African-American heritage and introduces a research agenda on the interrelation between tourism development and heritage recognition and the development of African-American heritage.

Part IV (Heritage tourism: the experiential turn) concentrates on the experiential turn of heritage tourism practices and offers. Dallen J. Timothy suggests a research agenda on new heritage perspectives and the experience economy in Chapter 13. The current, far more encompassing (in comparison with the past) understanding of heritage and the development of specific heritage tourism niches encourage the development of small-scale, personalized, segmented heritage tourism markets, which considerably transforms the heritage tourism settings. Daniela Angelina Jelinčić (Chapter 14) introduces a research agenda on emotions in heritage and makes the case for synesthetic experiences for heritage tourism visitors. Finally, in Chapter 15, Lorenzo Cantoni highlights the impacts of digital transformation on heritage tourism. He suggests a research agenda related to the multiple interactions between heritage tourism and ICT (information and communication technologies).

The multiplicity of perspectives, taking into consideration current evolutions in the concepts of both heritage and tourism, explains and justifies the multiplicity of research agendas suggested above on the rapidly evolving interrelation between heritage and tourism. The social, cultural, economic, political and geopolitical dimensions that heritage and tourism encompass today differ significantly from those of a few decades ago. It is clear that joint conceptual evolutions will continue in the years to come. The overall research agenda suggested by this book is to further explore the interconnection between these two reciprocally supported phenomena, heritage and tourism.

\section{References}

Adell, N., Bendix, R., Bortolotto, C. and Tauschek, M. (2015), Between Imagined Communities and Communities of Practice Participation: Territory and the Making of Heritage, Göttingen Studies in Cultural Property, Volume 8, Göttingen: Universitätsverlag Göttingen.

Alsayyad, N. (2013), Consuming Tradition, Manufacturing Heritage: Global Norms and Urban Forms in the Age of Tourism, London: Routledge. 
Ashworth, G. J. (2009), 'Do tourists destroy the heritage they have come to experience?', Tourism Recreation Research, 34(1), 79-83.

Berg, F. (2018), 'Wear and tear of world heritage: preventive conservation and tourism in Norway's stave churches', Studies in Conservation, 63(1), 320-22.

Botsman, R. and Rogers, R. (2011), What's Mine is Yours: How Collaborative Consumption is Changing the Way We Live, London: Collins.

Bourdeau, L., Gravari-Barbas, M. and Robinson, M. (2015), World Heritage: Tourism and Identity, London: Routledge.

Bourdeau, L., Gravari-Barbas, M. and Robinson, M. (2017), World Heritage Sites and Tourism: Global and Local Relations, London: Routledge.

Chhabra, D., Healy, R. and Sills, E. (2003), 'Staged authenticity and heritage tourism', Annals of Tourism Research, 30(3), 702-19.

Condevaux, A., Djament-Tran, G. and Gravari-Barbas, M. (2016), 'Before and after tourism(s). The trajectories of tourist destinations and the role of actors involved in "off-the-beaten-track" tourism: a literature review', Via Tourism Review, 9, https:// journals.openedition.org/viatourism/413.

Condevaux, A., Gravari-Barbas, M. and Guinand, S. (2019), Lieux ordinaires, avant et après le tourisme, Paris: PUCA.

Cousin, S. (2008), 'L’Unesco et la doctrine du tourisme culturel. Généalogie d'un "bon" tourisme', Civilisations, 57, 41-56, https://journals.openedition.org/civilisations/ 1541.

Delaplace, M. and Gravari-Barbas, M. (2016a), Nouveaux territoires touristiques. Invention, reconfigurations, repositionnement, Coll. 'Tourisme', Québec: Presses de l'université du Québec.

Delaplace, M. and Gravari-Barbas, M. (2016b), 'On the margins of tourism: utopias and realities of the off-the-beaten-track tourism', Via Tourism Review, 9, https://journals .openedition.org/viatourism/417?lang=en.

Frisch, T., Sommer, C., Stoltenberg, L. and Stors, N. (2019), Tourism and Everyday Life in the Contemporary City, London: Routledge.

Fyall, A. and Garrod, B. (1998), 'Heritage tourism: at what price?', Managing Leisure, 3(4), 213-28.

Garrod, B. (2009), 'Understanding the relationship between tourism destination imagery and tourist photography', Journal of Travel Research, 47(3), 346-58.

Gonzalez, M. V. (2008), 'Intangible heritage tourism and identity', Tourism Management, 29(4), 807-10.

Graham, B., Ashworth, G. J. and Tunbridge, J. E. (2000), A Geography of Heritage: Power, Culture and Economy, London: Arnold.

Gravari-Barbas, M. (2014), Nouveaux défis pour le patrimoine culturel [New Challenges for Cultural Heritage], Foresight Research, Agence Nationale pour la Recherche, https://www.pantheonsorbonne.fr/fileadmin/Colloques_IREST/Rapport_final_29 _04_14.pdf.

Gravari-Barbas, M. (2018), 'Tourism as a heritage-producing machine', Tourism Management Perspectives, 26, 5-8.

Gravari-Barbas, M. and Jacquot, S. (2008), 'Estimation de l'impact de l'inscription des sites du patrimoine mondial', sous la direction de Rémy Prudhomme, Report to the World Heritage Center of UNESCO.

Gravari-Barbas, M., Jacquot, S. and Cominelli, F. (2019), 'New cultures of urban tourism', International Journal of Tourism Cities, 5(3), 301-6. 
Grossi, E., Sacco, P.-L., Tavano Blessi, G. and Cerutti, R. (2011), 'The impact of culture on the subjective wellbeing of the Italian population: an exploratory study', Applied Research Quality Life, 6, 387-410.

Jansen-Verbeke, M. (1998), 'Tourismification of historical cities', Annals of Tourism Research, 25(3), 739-42.

Labadi, S. and Long, C. (2010), Heritage and Globalisation, London: Routledge.

Lazzarotti, O. (2003), 'Tourism and heritage: ad augusta per angustia', Annales de Géographie, 629, 91-110.

Maitland, R. (2010), 'Everyday life as a creative experience in cities', International Journal of Culture, Tourism and Hospitality, 4(3), 176-85.

Nicic, M. and Iguman, S. (2019), 'Post-socialism and "ordinary" tourism: New Belgrade', International Journal of Tourism Cities, 5(3), 307-25.

Park, H. y. (2010), 'Heritage tourism: emotional journeys into nationhood', Annals of Tourism Research, 37(1), 116-35.

Park, H. y. (2014), Heritage Tourism, New York: Routledge.

Peeters, P., Gössling, S., Klijs, J., Milano, C., Novelli, M., Dijkmans, C., Eijgelaar, E., Hartman, S., Heslinga, J., Isaac, R., Mitas, O., Moretti, S., Nawijn, J., Papp, B. and Postma, A. (2018), Overtourism: Impact and Possible Policy Responses, Brussels: European Parliament.

Poria, Y., Butler, R. and Airey, D. (2001), 'Clarifying heritage tourism', Annals of Tourism Research, 28(4), 1047-9.

Salazar, N. (2005), 'Tourism and glocalization: "local” tour guiding', Annals of Tourism Research, 32(3), 628-46.

Scarpaci, J. L. (2005), Plazas and Barrios: Heritage Tourism and Globalization in the Latin American Centro Historico, Tucson: University of Arizona Press.

Smith, L. (2012), 'The cultural "work" of tourism', in Smith, L., Waterton, E. and Watson, S. (eds), The Cultural Moment in Tourism, London: Routledge, 210-34.

Timothy, D. J. (1997), 'Tourism and the personal heritage experience', Annals of Tourism Research, 34(3), 751-4.

Timothy, D. (2011), Cultural Heritage and Tourism: An Introduction, Bristol: Channel View Publications.

Timothy, D. J. and Boyd, S. W. (2003), Heritage Tourism, Harlow: Prentice Hall.

Timothy, D. J. and Nyaupane, G. P. (2009), Cultural Heritage and Tourism in the Developing World: A Regional Perspective, London: Routledge.

Upton, D. (2013), 'Authentic anxieties', in Alsayyad, N. (ed.), Consuming Tradition, Manufacturing Heritage: Global Norms and Urban Forms in the Age of Tourism, London: Routledge, 298-306.

Urry, J. (1990), The Tourist Gaze: Leisure and Travel in Contemporary Societies, London: Sage.

Waterton, E. and Watson, S. (2014), The Semiotics of Heritage Tourism, Bristol: Channel View Publications.

Xie, Ph. F. (2015), Industrial Heritage Tourism, Bristol: Channel View Publications. 